\title{
Silane Modification of Starch-Based Wood Adhesive: Review
}

\author{
Ravindra V. Gadhave*, Praneeta Sheety, Prakash A. Mahanwar, Pradeep T. Gadekar, \\ Bilvesh J. Desai
}

Department of Polymer and Surface Engineering, Institute of Chemical Technology, Mumbai, India

Email: ${ }^{\star}$ ravi.gadhave3@gmail.com

How to cite this paper: Gadhave, R.V., Sheety, P., Mahanwar, P.A., Gadekar, P.T. and Desai, B.J. (2019) Silane Modification of Starch-Based Wood Adhesive: Review. Open Journal of Polymer Chemistry, 9, 53-62. https://doi.org/10.4236/ojpchem.2019.93005

Received: July 26, 2019

Accepted: August 24, 2019

Published: August 27, 2019

Copyright () 2019 by author(s) and Scientific Research Publishing Inc. This work is licensed under the Creative Commons Attribution International License (CC BY 4.0).

http://creativecommons.org/licenses/by/4.0/

\section{(c) (i) Open Access}

\begin{abstract}
Currently there has been a growing interest in substituting traditional synthetic polymers with biobased renewable polymers for adhesive applications. However, biobased renewable polymers such as starch suffer from few draw-backs like poor water resistance and mechanical strength. To become important potential alternatives of synthetic polymers, starch must have comparable physical, chemical, thermal and mechanical properties to that of synthetic polymers. To achieve this, starch has been modified by a series of crosslinkers like boric acid, citric acid, glyoxal, gluteraldehyde, etc. and silane modification. Silane modification by chloropropyl trimethoxysilane, $\gamma$-Methacryloxypropyl trimethoxy silane and vinyl trimethoxy silane is a suitable method to improve the performance in terms of mechanical and thermally. Silane forms covalent bonds with starch during starch modification resulted in enhanced shear strength and storage stability. A new research on biodegradable, renewable, environmentally friendly silane modification of starch-based wood adhesive that was prepared by reacting with various silanes. This paper, we reviewed silane as a modifying agent for starch-based wood adhesive.
\end{abstract}

\section{Keywords}

Starch, Silane, Wood, Adhesive, Coupling Agents

\section{Introduction}

Polyvinyl acetate (PVAc) emulsions are commonly used in bonding porous materials at room temperature. PVAc emulsions are prepared by free radical polymerizing vinyl acetate (VAc) monomers in the presence of polyvinyl alcohol as a protective colloid. PVAc adhesive manufacturing is depended on vinyl acetate 
monomer which will get from petroleum resources. The effective use of renewable cellulosic polymers as wood adhesive, which has been shown to have some, promising properties comparable to traditionally used synthetic polymers can successfully reduce the use of petroleum resources [1]-[8]. With the development of wood-based composites, wood adhesives play a significant role in furniture, construction and building industries [9]. However, most of the wood adhesives are produced from petroleum resources such as urea-formaldehyde, phenol-formaldehyde and melamine-formaldehyde that cannot be sustained in the long run. Moreover, In the process of the production and application, a large amount of formaldehyde will be released leading to environmental pollution and harm to public health [10]-[15]. Therefore, it is very important to develop nontoxic and environmentally friendly wood adhesives based on renewable resources in future research [16]. At present, several renewable biopolymers, such as soybean protein, natural tannin and starch [17] [18] [19] [20], had been used to prepare environment-friendly wood adhesives.

Starch has many diverse applications in food production and other industries [21]. Chemically modified starches extend the range of physical properties available for various uses, because they exhibit excellent physicochemical properties that are markedly altered from those of their parent starches [22] [23]. Starches have been widely used in the adhesives industry, but their bonding capacity is insufficient for gluing wood. Never the less, these starch-based wood adhesives still lack the high bonding strength and water resistance. The molecular structure of starch adhesives must be strengthened to develop high-performance wood adhesive [24].

Starch oxidation, an alternative method for improving starch properties, is widely used in the industry. Oxidation is a chemical modification in which carboxyl and carbonyl functional groups can be introduced into the starch chains. At a suitable temperature and $\mathrm{pH}$, starch can react with several oxidizing reagents [25] [26] [27] to form oxidized starch. Oxidized starch prepared from hydrogen peroxide has been of particular research interest [28] [29]. Hydroxyl groups, primarily at the C-2, C-3, and C-6 positions, are transformed into carbonyl or carboxyl groups via oxidation [30] [31]. However, the carbonyl and carboxyl groups exhibit high-activity, easily participating in various reactions, such as cross-linking [33]. Hydrogen peroxide decomposes into hydrogen ions and water, making it an environmentally friendly oxidizing reagent. The oxidized starch adhesive exhibited low bonding strength and water resistance preventing its use in practical applications. Therefore, in order to improve the performance of starch adhesives, sodium dodecyl sulfate [32], urea [33], however, during the last few decades, environmental friendly natural polymers have attracted greater attention all over the world due to the increasing environmental awareness as well as the depletion of petroleum-based resources [34] [35] [36]. Due to their inherent properties such as renewable nature, biodegradability, economic, easy availability, natural polymers are emerging as viable alternatives 
to traditional petroleum-based materials [37] [38] [39].

The bonding strength and thermal properties of the starch-based adhesive have improved significantly, con-firming the positive effect of adding the silane coupling agent and olefin monomer to the adhesive system. Silane coupling agent is commonly used to strengthen the interfacial interaction between starch hydroxyl groups. For the adhesive, organo-silanes can combine with starch to form a very thin coat, and the $\mathrm{C}$-Si-O-connects with the hydrogen bonding on the surface of the wood. In this paper, we reviewed modification of starch by silane to improve performance properties of starch-based adhesive.

\section{Silane Modification of Starch-Based Adhesive}

Silane coupling agent was added to the starch to produce a silane modified wood adhesive [40] [41] [42] as shown in Figure 1. The bonding strength and water resistance of the adhesive had improved significantly, confirming the positive effect of adding the silane coupling agent to the adhesive system [43] [44].

Cellulose fibers exhibit the potential to replace traditional synthetic fibers as reinforcement in the production of cellulose-fiber-reinforced green composites [45]-[51]. However, the hydrophilic nature of these cellulosic fibers limits their applications as it results in poor chemical as well as moisture absorption resistance. In the case of poly lactic acid (PLA) and silane treated starch blends, they were widely reported but mainly focused on the changes in mechanical and thermal properties [52] [53]. In the first step, a systematic study of coupling reaction between organo functional silane coupling agents and starch to clarify the optimal type of silane was carried out. In the second step, the use of the obtained starch coupling with silane for the reactive blend with PLA was shown as in Figure 2.
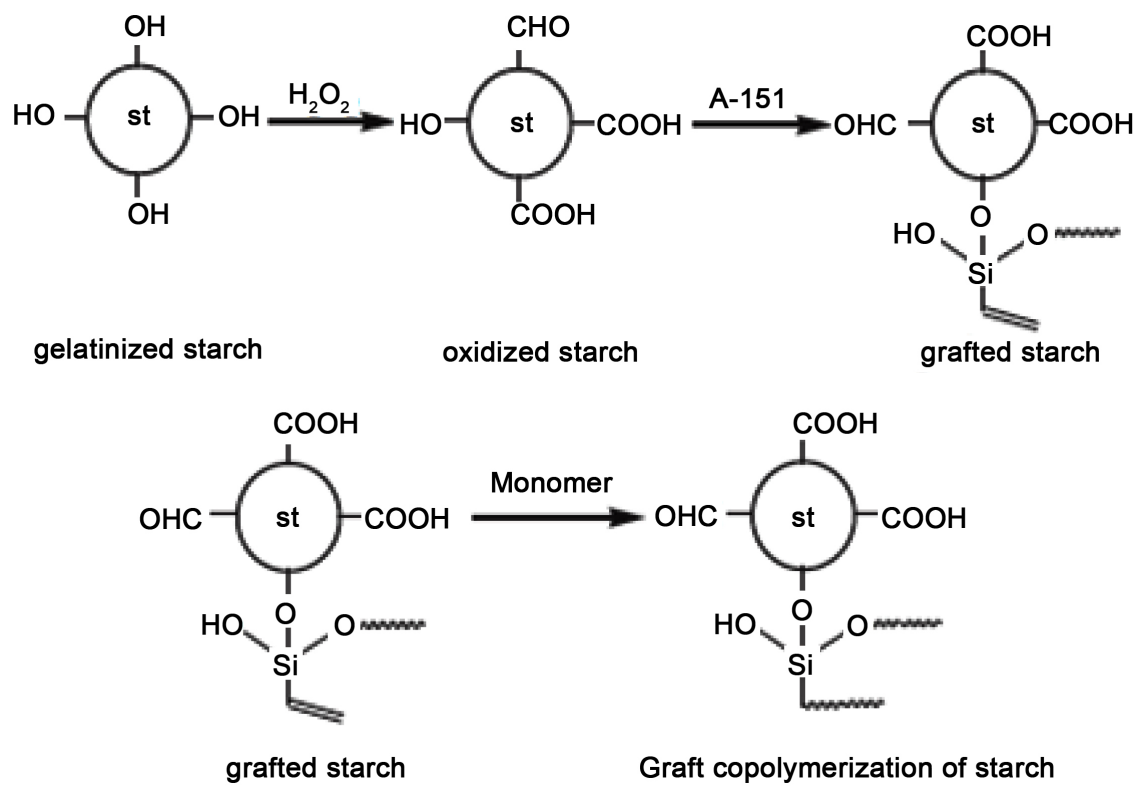

Figure 1. Silane modification of monomer grafted starch [2]. 


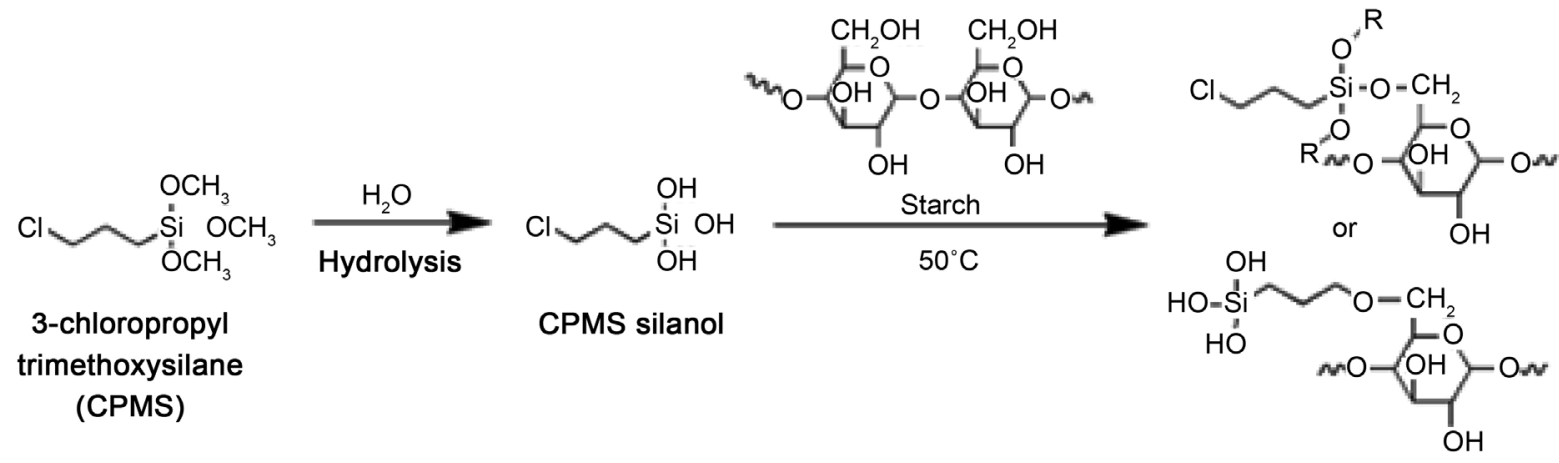

CPMS modified starch

(CP-starch)

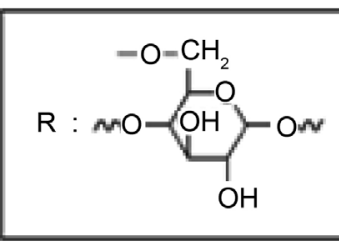

$\underbrace{C}_{\mathrm{CH}_{3}}$<smiles>CC(O)C(=O)OC(C)(C)C(=O)OC(C)(C)C(=O)OC(C)C(=O)O</smiles>

Reactive PLA/CP-starch blend

Figure 2. Starch coupling reaction with silane [54].

Starch-based wood adhesive prepared by grafting vinyl acetate onto the starch backbone shows better properties [55]. In addition, silane coupling agent was also used to produce the oxidized starch graft copolymerized wood adhesive with high bonding strength and water resistance [43] [56] and reinforced soy protein adhesive [57]. For the adhesive, organo-silanes can combine with starch or VAc to form a very thin coat, and the C-Si-O-connects with the hydrogen bonding in the surface of wood [58]. Silane coupling agents from the initial research are generally addition for the thermosetting resins, fillers and substrates to improve the dispersion forces and flow behavior [59]. However, KH570 is one of the most commonly used coupling agent with a better reactivity for vinyl acetate, and the acyloxy groups in $\mathrm{KH} 570$ as a coupling agent to prepare starch-based wood adhesives and investigated the improvements such as bonding strength, stability, structures and morphologies using different analytical techniques.

The alkoxy silanes have been demonstrated to be able to directly react with -Si-OH groups of silica thereby forming -Si-O-Si- bonds without any requirement of pre-hydrolysis. However, silanes do not undergo the same reaction with the hydroxyl groups of starch/PVA even at high temperature. This has been attributed to lower acidity of starch/PVA hydroxyl groups compared with silanol. 
In addition, starch/PVA is generally un-reactive to many chemicals and the $\mathrm{OH}$ groups have very low accessibility [19]. Based on the fact, an optional strategy is to activate the alkoxy silane by hydrolyzing the alkoxy groups off thereby forming the more reactive silanol groups. As a result, the silanol may react with the hydroxyl groups of fibers or condense themselves on the surfaces of fibers and/or in the cell walls forming macromolecular network Figure 3.

\section{Conclusion}

High water resistance and bonding strength of starch-based wood adhesive can

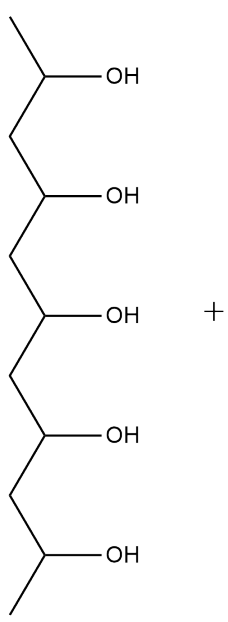

$\mathrm{PVA} / \mathrm{S}$

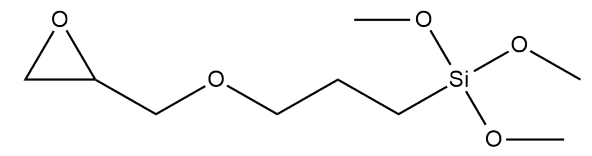

Epoxy silane

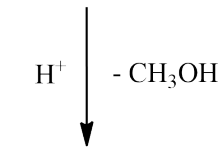

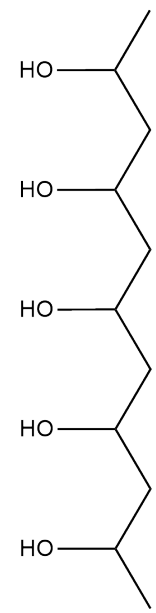

$\mathrm{PVA} / \mathrm{S}$

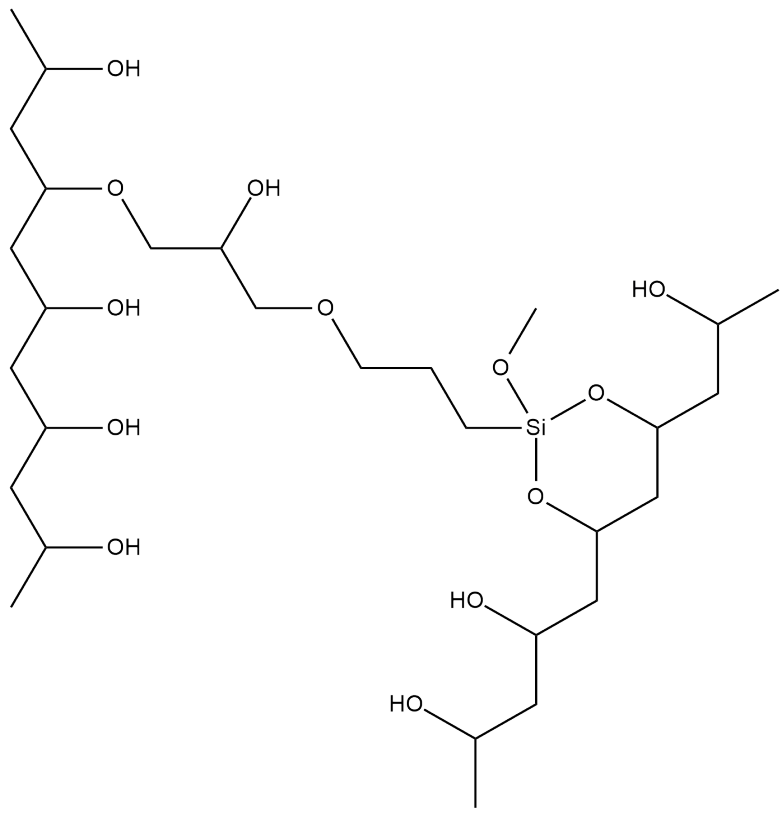

PVA/S crosslinked with epoxy silane

Figure 3. PVA/S crosslinked with epoxy silane [60]. 
be synthesized via the copolymerization of starch with a coupling agent and monomer. The improvement in the properties of the starch-based wood adhesive with the addition of the coupling agent was supported by its better compatibility and more covalent bonds formation that resulted in enhanced thermal stability and increased bonding strength. The cross-linking reaction had resulted in the formation of covalent bonds between the silanol bonds and hydroxy groups. The organic end of coupling agent reacted with starch, and another end was used for grafting and forming chemical bonds across the wood interface to enhance the bonding strength.

\section{Conflicts of Interest}

The authors declare no conflicts of interest regarding the publication of this paper.

\section{References}

[1] Rani, P., Sen, G., Mishra, S. and Jha, U. (2012) Microwave Assisted Synthesis of Polyacrylamide Grafted Gum Ghatti and Its Application as Flocculant. Carbohydrate Polymers, 89, 275-281. https://doi.org/10.1016/j.carbpol.2012.03.009

[2] Thakur, V.K., Thakur, M.K. and Gupta, R.K. (2013) Graft Copolymers from Natural Polymers Using Free Radical Polymerization. International Journal of Polymer Analysis and Characterization, 18, 495-503. https://doi.org/10.1080/1023666X.2013.814241

[3] Gadhave, R.V., Mahanwar, P.A. and Gadekar, P.T. (2017) Starch-Based Adhesives for Wood/Wood Composite Bonding: Review. Open Journal of Polymer Chemistry, 7, 19-32. https://doi.org/10.4236/ojpchem.2017.72002

[4] Gadhave, R.V., Mahanwar, P.A. and Gadekar, P.T. (2018) Starch Stabilized Polyvinyl Acetate Emulsion: Review. Polymers from Renewable Resources, 9, 75-84. https://doi.org/10.1177/204124791800900203

[5] Salon, M.C.B., Bayle, P.A., Abdelmouleh, M., Boufi, S. and Belgacem, M.N. (2008) Kinetics of Hydrolysis and Self-Condensation Reaction of Silanes by NMR Spectroscopy. Colloids and Surfaces A: Physicochemical and Engineering Aspects, 312, 83-91. https://doi.org/10.1016/j.colsurfa.2007.06.028

[6] Donath, S., Militz, H. and Mai, C. (2006) Creating Water-Repellent Effects on Wood by Treatment with Silanes. Holzforschung, 60, 40-46. https://doi.org/10.1515/HF.2006.008

[7] Abdelmouleh, M., Boufi, S., Ben Salah, A., Belgacem, M.N. and Gandini, A. (2002) Interaction of Silane Coupling Agents with Cellulose. Langmuir, 18, 3203-3208. https://doi.org/10.1021/la011657g

[8] Thakur, V.K., Singha, A.S. and Thakur, M.K. (2011) Biopolymers Based Green Composites: Mechanical, Thermal and Physico-Chemical Characterization. Journal of Polymers and the Environment, 20, 412-421. https://doi.org/10.1007/s10924-011-0389-y

[9] Li, Z., Wang, J., Li, C., Gu, Z., Cheng, L.Y. and Hong, Y. (2015) Effects of Montmorillonite Addition on the Performance of Starch-Based Wood Adhesive. Carbohydrate Polymers, 115, 394-400. https://doi.org/10.1016/j.carbpol.2014.08.106

[10] Xin, S., Zeng, Z., Zhou, X., Luo, W., Shi, X., Wang, Q., Deng, H. and Du, Y. (2017) 
Recyclable Saccharomyces cerevisiae Loaded Nanofibrous Mats with Sandwich Structure Constructing via Bio-Electro Spraying for Heavy Metal Removal. Journal of Hazardous Materials, 324, 365-372. https://doi.org/10.1016/j.jhazmat.2016.10.070

[11] Lei, H., Du, G., Wu, Z., Xi, X. and Dong, Z. (2014) Cross-Linked Soy-Based Wood Adhesives for Plywood. International Journal of Adhesion and Adhesives, 50, 199-203. https://doi.org/10.1016/j.ijadhadh.2014.01.026

[12] Zdanowicz, M., Schmidt, B. and Spychaj, T. (2010) Starch Graft Copolymers as Super-Absorbents Obtained via Reactive Extrusion Processing. Polish Journal of Chemical Technology, 12, 14-17. https://doi.org/10.2478/v10026-010-0012-3

[13] Moubarik, A., Mansouri, H., Pizzi, A., Allal, A., Charrier, F. and Badia, M. (2013) Evaluation of Mechanical and Physical Properties of Industrial Particleboard Bonded with a Corn Flour-Urea Formaldehyde Adhesive. Composites Part B: Engineering, 44, 48-51. https://doi.org/10.1016/j.compositesb.2012.07.041

[14] Lin, Q., Chen, N., Bian, L. and Fan, M. (2012) Development and Mechanism Characterization of High Performance Soy-Based Bio-Adhesives. International Journal of Adhesion and Adhesives, 34, 11-16. https://doi.org/10.1016/j.ijadhadh.2012.01.005

[15] Yang, X., Zhang, Y. and Chen, D. (2001) Eye Irritation Caused by Formaldehyde as an Indoor Air Pollution a Controlled Human Exposure Experiment. Biomedical and Environmental Sciences, 14, 229-236.

[16] Gui, C., Wang, G., Wu, D., Zhu, J. and Liu, X. (2013) Synthesis of a Bio-Based Polyamidoamine-Epichlorohydrin Resin and Its Application for Soy-Based Adhesives. International Journal of Adhesion and Adhesives, 44, 237-242. https://doi.org/10.1016/j.ijadhadh.2013.03.011

[17] Gao, Q., Shi, S., Li, J., Liang, K. and Zhang, X. (2012) Soybean Meal-Based Wood Adhesives Enhance by Modified Polyacrylic Acid Solution. BioResources, 7, 946-956.

[18] Li, K., Geng, X., Simonsen, J. and Karchesy, J. (2004) Novel Wood Adhesives from Condensed Tannins and Polyethylenimine. International Journal of Adhesion and Adhesives, 24, 327-333. https://doi.org/10.1016/j.ijadhadh.2003.11.004

[19] Li, Z., Wang, J., Cheng, L., Gu, Z., Hong, Y. and Kowalczyk, A. (2014) Improving the Performance of Starch-Based Wood Adhesive by Using Sodium Dodecyl Sulfate. Carbohydrate Polymers, 99, 579-583. https://doi.org/10.1016/j.carbpol.2013.08.062

[20] Déborah, L., Julien, B. and Alain, D. (2010) Starch Nanoparticles: A Review. Biomacromolecules, 11, 1139-1153. https://doi.org/10.1021/bm901428y

[21] Gadhave, R., Das, A., Mahanwar, P. and Gadekar, P. (2018) Starch-Based Bio-Plastics: The Future of Sustainable Packaging. Open Journal of Polymer Chemistry, 8, 21-33. https://doi.org/10.4236/ojpchem.2018.82003

[22] Zhang, S.D., Zhang, Y.R., Zhu, J., Wang, X.L., Yang, K.K. and Wang, Y.Z. (2007) Modified Corn Starches with Improved Comprehensive Properties for Preparing Thermoplastics. Starch, 59, 258-268. https://doi.org/10.1002/star.200600598

[23] Kennedy, H.M. (1989) Starch- and Dextrin-Based Adhesives. Adhesives from Renewable Resources. American Chemical Society, 385, 326-336. https://doi.org/10.1021/bk-1989-0385.ch023

[24] Veelaert, S., de Wit, D., Gotlieb, K.F. and Verhé, R. (1997) Chemical and Physical Transitions of Periodate Oxidized Potato Starch in Water. Carbohydrate Polymers, 33, 153-162. https://doi.org/10.1016/S0144-8617(97)00046-5

[25] Kuakpetoon, D.S. and Wang, Y.J. (2001) Characterization of Different Starches 
Oxidized by Hypochlorite. Starch, 53, 211-218.

https://doi.org/10.1002/1521-379X(200105)53:5<211::AID-STAR211>3.0.CO;2-M

[26] Wing, R.E. and Willett, J.L. (1997) Water Soluble Oxidized Starches by Peroxide Reactive Extrusion. Industrial Crops and Products, 7, 45-52.

https://doi.org/10.1016/S0926-6690(97)00069-1

[27] El-Sheikh, M., Ramadan, M. and El-Shafie, A. (2010) Photo Oxidation of Rice Starch I. Using Hydrogen Peroxide. Carbohydrate Polymers, 80, 266-269. https://doi.org/10.1016/j.carbpol.2009.11.023

[28] Zhang, S.D., Zhang, Y.R., Wang, X.L. and Wang, Y.Z. (2009) High Carbonyl Content Oxidized Starch Prepared by Hydrogen Peroxide and Its Thermoplastic Application. Starch, 61, 646-655. https://doi.org/10.1002/star.200900130

[29] Kuakpetoon, D. and Wang, Y. (2006) Structural Characteristics and Physicochemical Properties of Oxidized Corn Starches Varying in Amylose Content. Carbohydrate Research, 341, 1896-1915. https://doi.org/10.1016/j.carres.2006.04.013

[30] Kurakake, M., Akiyama, Y., Hagiwara, H. and Komaki, T. (2009) Effects of CrossLinking and Low Molecular Amylose on Pasting Characteristics of Waxy Corn Starch. Food Chemistry, 116, 66-70. https://doi.org/10.1016/j.foodchem.2009.02.006

[31] Yanbo, W., Chengfei, L. and Meina, H. (2009) Synthesis and Performance Study of Polybasic Starch Graft Copolymerization Function Materials. Advanced Materials Research, 79-82, 43-46. https://doi.org/10.4028/www.scientific.net/AMR.79-82.43

[32] Wang, Z., Gu, Z., Li, Z., Hong, Y. and Cheng, L. (2013) Effects of Urea on Freeze-Thaw Stability of Starch-Based Wood Adhesive. Carbohydrate Polymers, 95, 397-403. https://doi.org/10.1016/j.carbpol.2013.02.009

[33] Fishman, M.L., Coffin, D.R., Konstance, R.P. and Onwulata, C.I. (2000) Extrusion of Pectin/Starch Blends Plasticized with Glycerol. Carbohydrate Polymers, 41, 317-325. https://doi.org/10.1016/S0144-8617(99)00117-4

[34] Bharti, S., Mishra, S. and Sen, G. (2013) Ceric Ion Initiated Synthesis of Polyacrylamide Grafted Oatmeal: Its Application as Flocculantfor Wastewater Treatment. Carbohydrate Polymers, 93, 528-536. https://doi.org/10.1016/j.carbpol.2012.11.072

[35] Thakur, V.K., Thakur, M.K. and Gupta, R.K. (2013) Development of Functionalized Cellulosic Biopolymers by Graft Copolymerization. International Journal of Biological Macromolecules, 62, 44-51. https://doi.org/10.1016/j.ijbiomac.2013.08.026

[36] Thakur, V.K., Thakur, M.K. and Gupta, R.K. (2014) Graft Copolymers of Natural Fibers for Green Composites. Carbohydrate Polymers, 104, 87-93.

https://doi.org/10.1016/j.carbpol.2014.01.016

[37] Basta, A.H., El-Saied, H., El-Hadi, O. and El-Dewiny, C. (2013) Evaluation of Rice Straw-Based Hydrogels for Purification of Wastewater. Polymer-Plastics Technology and Engineering, 52, 1074-1080. https://doi.org/10.1080/03602559.2013.806548

[38] Rani, G.U., Mishra, S., Sen, G. and Jha, U. (2012) Polyacrylamide Grafted Agar: Synthesis and Applications of Conventional and Microwave Assisted Technique. Carbohydrate Polymers, 90, 784-791. https://doi.org/10.1016/j.carbpol.2012.05.069

[39] Thakur, V.K., Thakur, M.K. and Gupta, R.K. (2013) Graft Copolymers from Cellulose: Synthesis, Characterization and Evaluation. Carbohydrate Polymers, 97, 18-25. https://doi.org/10.1016/j.carbpol.2013.04.069

[40] Bruyn, H.D., Sprong, E., Gaborieau, M., Rober, J.A. and Gilbert, R.G. (2007) Starch-Graft-(Synthetic Copolymer) Latexes Initiated with $\mathrm{Ce}^{4+}$ and Stabilized by Amylopectin. Journal of Polymer Science Part A: Polymer Chemistry, 45, 4185-4192. 
https://doi.org/10.1002/pola.22189

[41] Gong, Q., Wang, L.-Q. and Tu, K. (2006) In Situ Polymerization of Starch with Lactic Acid in Aqueous Solution and the Microstructure Characterization. Carbohydrate Polymers, 64, 501-509. https://doi.org/10.1016/j.carbpol.2005.09.005

[42] Tanrattanakul, V. and Chumeka, W. (2010) Effect of Potassium Persulfate on Graft Copolymerization and Mechanical Properties of Cassava Starch/Natural Rubber Foams. Journal of Applied Polymer Science, 116, 93-105. https://doi.org/10.1002/app.31514

[43] Wang, Z.J., Gu, Z.B., Hong, Y., Cheng, L. and Li, Z.F. (2011) Bonding Strength and Water Resistance of Starch-Based Wood Adhesive Improved by Silica Nanoparticles. Carbohydrate Polymers, 86, 72-76. https://doi.org/10.1016/j.carbpol.2011.04.003

[44] Bordes, P., Pollet, E. and Avérous, L. (2009) Nano-Biocomposites: Biodegradable Polyester/Nanoclay Systems. Progress in Polymer Science, 34, 125-155. https://doi.org/10.1016/j.progpolymsci.2008.10.002

[45] Khoathane, M.C., Vorster, O.C. and Sadiku, E.R. (2008) Hemp Fiber-Reinforced 1-Pentene/Polypropylene Copolymer: The Effect of Fiber Loading on the Mechanical and Thermal Characteristics of the Composites. Journal of Reinforced Plastics and Composites, 27, 1533-1544. https://doi.org/10.1177/0731684407086325

[46] Thakur, V.K., Singha, A.S. and Thakur, M.K. (2012) Green Composites from Natural Fibers: Mechanical and Chemical Aging Properties. International Journal of Polymer Analysis and Characterization, 17, 401-407. https://doi.org/10.1080/1023666X.2012.668665

[47] Thakur, V.K., Singha, A.S. and Thakur, M.K. (2013) Fabrication and Physico-Chemical Properties of High-Performance Pine Needles/Green Polymer Composites. International Journal of Polymeric Materials and Polymeric Biomaterials, 62, 226-230. https://doi.org/10.1080/00914037.2011.641694

[48] Dhakal, H.N., Zhang, Z.Y., Reis, P.N.B., Surip, S.N. and Bennett, N. (2012) Evaluation of Water Absorption Damage in Hemp Fibre Reinforced Unsaturated Polyester Composites by the Nanoindentation Testing. Journal of Biobased Materials and Bioenergy, 6, 493-499. https://doi.org/10.1166/jbmb.2012.1230

[49] Khalil, H.P.S.A., Jawaid, M., Firoozian, P., Amjad, M., Zainudin, E. and Paridah, M.T. (2013) Tensile, Electrical Conductivity and Morphological Properties of Carbon Black-Filled Epoxy Composites. International Journal of Polymer Analysis and Characterization, 18, 329-338. https://doi.org/10.1080/1023666X.2013.782841

[50] Thakur, V.K., Thakur, M.K. and Gupta, R.K. (2013) Synthesis of Lignocellulosic Polymer with Improved Chemical Resistance through Free Radical Polymerization. International Journal of Biological Macromolecules, 61, 121-126.

https://doi.org/10.1016/j.ijbiomac.2013.06.045

[51] Thakur, V.K., Thakur, M.K. and Gupta, R.K. (2013) Eulaliopsis binata: Utilization of Waste Biomass in Green Composites. In: Green Composites from Natural Resources, CRC Press, Boca Raton, FL. http://www.crcnetbase.com/doi/abs/10.1201/b16076-7

[52] Liu, R., Cao, J. and Ou-Yang, L. (2013) Degradation of Wood Flour/Poly(Lactic Acid) Composites Reinforced by Coupling Agents and Organo-Montmorillonite in a Compost Test. Wood and Fiber Science, 45, 105-118.

[53] Pilla, S., Gong, S., O’Neill, E., Rowell, R.M. and Krzysik, A.M. (2008) Polylactide-Pine Wood Flour Composites. Polymer Engineering and Science, 48, 578-587. https://doi.org/10.1002/pen.20971 
[54] Jariyasakoolroj, P. and Chirachanchai, S. (2014) Silane Modified Starch for Compatible Reactive Blend with Poly (Lactic Acid). Carbohydrate Polymers, 106, 255-263. https://doi.org/10.1016/j.carbpol.2014.02.018

[55] Jiang, L., Lu, Y., Liu, X., Tu, H., Zhang, J., Shi, X., Deng, H. and Du, Y. (2015) Layerby-Layer Immobilization of Quaternized Carboxymethyl Chitosan/Organic Rectorite and Alginate onto Nanofibrous Mats and Their Antibacterial Application. Carbohydrate Polymers, 121, 428-435. https://doi.org/10.1016/j.carbpol.2014.12.069

[56] Zhang, Y., Ding, L., Gu, J., Tan, H. and Zhu, L. (2015) Preparation and Properties of a Starch-Based Wood Adhesive with High Bonding Strength and Water Resistance. Carbohydrate Polymers, 115, 32-37. https://doi.org/10.1016/j.carbpol.2014.08.063

[57] Li, C., Li, Y., Zhang, S. and Li, Z. (2014) Preparation of Reinforced Soy Protein Adhesive Using Silane Coupling Agent as an Enhance. BioResources, 9, 5448-5460. https://doi.org/10.15376/biores.9.3.5448-5460

[58] Petrie, E.M. (1999) Handbook of Adhesives and Sealants. McGraw-Hill Professional, New York, 266-277.

[59] Heo, G. and Park, S. (2012) Effect of Coupling Agents on Thermal, Flow and Adhesion Properties of Epoxy/Silica Compounds for Capillary under Fill Applications. Powder Technology, 230, 145-150. https://doi.org/10.1016/j.powtec.2012.07.022

[60] Gadhave, R.V., Mahanwar, P.A. and Gadekar, P.T. (2019) Cross-Linking of Polyvinyl Alcohol/Starch Blends by Epoxy Silane for Improvement in Thermal and Mechanical Properties. BioResources, 14, 3833-3843. 